\title{
Unpacking domestic preferences in the policy-'receiving' state: the EU's migration cooperation with Senegal and Ghana
}

\author{
Melissa Mouthaan (1)
}

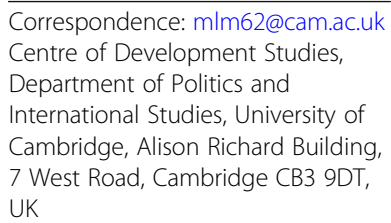

Correspondence: mlm62@cam.ac.uk Centre of Development Studies, Department of Politics and International Studies, University of Cambridge, Alison Richard Building, 7 West Road, Cambridge CB3 9DT, UK

\begin{abstract}
Drawing on interviews conducted in Brussels, Dakar and Accra between September 2017-March 2018, this paper discusses the responses of domestic policy actors to the EU's migration policy proposals in the two West African countries of Senegal and Ghana. EU-African cooperation in migration is mediated by the domestic context that the EU's migration agenda is 'received' in, and the preferences and responses of policy communities in the countries that are the intended recipients of the EU's governance approach. While existing studies have examined preference formation on the part of European actors in the EU's external migration agenda, the preferences and agency of African actors and how these shape the EU's external migration governance remain under-examined. Looking primarily at domestic contestation in the area of returns and readmission, this paper demonstrates that the preferences of policy actors in the receiving country are formed in a shifting domestic context and have an impact in determining the ability of the EU to achieve its aims and preferred governance strategy. In addition, it is shown that organisational and bureaucratic dynamics can influence cooperation outcomes.
\end{abstract}

Keywords: Migration, West Africa, EU, Policy, Sociological institutionalism, Organisational sociology, Externalisation, Senegal, Ghana

\section{Introduction}

The growing literature on the EU's migration policy 'externalisation' in non-EU countries has given key insights into the outcomes of cooperation in migration, as well as processes of policy convergence in line with an EU agenda in migration. Such scholarship has demonstrated the processes by which the EU and its Member States strive to implement policies and frameworks that promote the governing of EU borders outside of its actual borders and jurisdiction (Andersson, 2014; Aubarell, Zapata-Barrero, \& Aragall, 2009; Betts, 2011; Boswell, 2003; Lavenex \& Uçarer, 2004; Samers, 2004). Yet, the picture that emerges is one where the EU is sometimes, but not always, successful in achieving its policy preferences in negotiation with non-EU partner countries, as recent historical efforts to converge third countries' migration policies in line with the EU agenda have seen mixed results. ${ }^{1}$ The EU's success in achieving formal migration

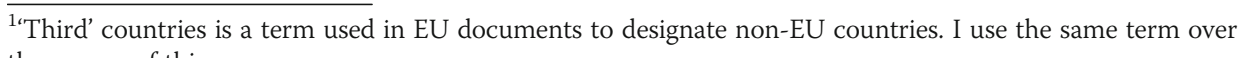
the course of this paper.

(c) The Author(s). 2019, corrected publication 2019. Open Access This article is distributed under the terms of the Creative Commons Attribution 4.0 International License (http://creativecommons.org/licenses/by/4.0/), which permits unrestricted use, distribution, and reproduction in any medium, provided you give appropriate credit to the original author(s) and the source, provide a link to the Creative Commons license, and indicate if changes were made. 
cooperation in African countries has largely occurred when the aims and priorities of African political counterparts converged with the EU's aims; even in those instances African countries can be seen to have implemented policies 'à la carte' (Wunderlich, 2010). The EU's failure in securing a Mobility Partnership with Senegal (Chou \& Gibert, 2012; Reslow \& Vink, 2015) is also evidence of a mixed track record in attaining migration policy preferences in West Africa. The success of the EU's pursuit of its migration policy preferences in third countries is far from a fait accompli from the outset: it is often dependent on factors such as the relative strategic strength of third countries' positions in relation to the EU, the perception of the EU as an effective actor, and the willingness of the third country to participate in joint cooperation schemes based on perceived cost and benefit. At the same time, the EU's geographical and partnership ambitions in the area of migration have continued to expand: the EU's Partnership Framework, proposed in 2016, builds on 'lessons learned' in the course of the EU's external migration policy implementation over the last decade. It details a roadmap for further EU involvement in the migration governance of 16 'priority countries'. Of these 16 countries, 13 are located in Africa. ${ }^{2}$ The EU Emergency Trust Fund for Africa (EUTF), an EU tool and funding mechanism introduced in November 2015, is the financial backbone to the Partnership Framework and constitutes a major scaling up of the EU's migration ambitions in, primarily, sub-Saharan Africa.

Institutionalist literature has provided much of the existing scholarship on theorising EU external migration governance and negotiation outcomes. A distinction can be made between rational choice institutionalism and sociological or constructivist theories on the other hand. Rational choice institutionalism examines international negotiations from the perspective of 'goal-seeking under constraints' (Snidal, 2002, p.74). In a rationalist model, bargaining strategies are adapted to attain preferences, where preference formation is external to the broader institutional context that actors operate in. The rationalist approach has been widely applied in the Europeanisation literature, which adopts a policy transfer lens and points to eventual accession to the Union as an important incentive for cooperation with the EU (Graziano \& Vink, 2007; Lavenex \& Schimmelfennig, 2009; Schimmelfennig \& Sedelmeier, 2004; Wunderlich, 2012). Sociological institutionalism stresses the importance of norms, socialisation, rules, and practices in the formation of policy and in decision-making processes (Checkel, 2005; Finnemore \& Sikkink, 1998; Katzenstein, 1984; Pollack, 2007). These perspectives point to the importance of the 'appropriateness' of the proposed policy or agreement in terms of its coherence with actors' notions of their identities and roles, and with formal or informal rules. Rule-guided behaviour may be unconscious but is also often a deliberate process, where actors seek to decipher a situation and apply the appropriate norm according to their given identities (March \& Olsen, 1989; Risse, 2000). Policy-making actors for example make decisions that are likely to reinforce their legitimacy, rather than detract from it. Institutional norms may on the other hand constrain the ability of policy-makers to implement wide-ranging changes (Bonjour, Ripoll Servent, \& Thielemann, 2018).

\footnotetext{
${ }^{2}$ The 16 priority countries listed: Ethiopia, Eritrea, Mali, Niger, Nigeria, Senegal, Somalia, Sudan, Ghana, Côte d'Ivoire, Algeria, Morocco, Tunisia, Afghanistan, Bangladesh and Pakistan.
} 
The two logics of political action are not necessarily mutually exclusive, as actors may for example pursue non-material goals but consequentialism (means and ends calculations) may still underlie policy choices (Checkel, 2001). A case can therefore be made to use both simultaneously (Börzel \& Risse, 2003; Checkel, 2001; Risse, 2000). This paper accordingly draws on institutionalist approaches to demonstrate that state actors in policy 'recipient' countries can be shown to adopt both a logic of appropriateness, and a logic of expected consequences, in line with existing ideas around 'bridging' rationalist and sociological or constructivist approaches (Thielemann, 2001; Zürn \& Checkel, 2005).

This article is positioned as follows. The formation of the EU's external migration policy as a result of competing actors at the national and regional level seeking to exert their influence - and using the external 'venue' to do so - has been well documented using an institutionalist lens (e.g. Guiraudon, 2000, Guiraudon, 2003, Lavenex, 1999, Lavenex \& Schimmelfennig, 2009). In comparison, actor-centred studies in policy-'receiving' countries and analyses of institutional dynamics that inform policy formation in these countries are more limited. Studies have, moreover, focused on external incentives for third countries to cooperate with the EU on migration (e.g. Schimmelfennig \& Sedelmeier, 2004) or on the limits of EU institutional and political power in negotiations with third countries (e.g. Hampshire, 2016). The agency of African actors and their role in shaping migration cooperation is more commonly negated due to the asymmetry of power dynamics between EU and African countries (El Qadim, 2015; Van Criekinge, 2010). Power-based arguments have stressed that the negotiating power of the EU and its Member States far exceeds that of individual African states. While this is a generally uncontested assertion, African actors are not merely 'passive agents' in the EU's external migration governance and the role of local actors in determining migration cooperation outcomes can be significant, as a few studies have demonstrated (notably: Van Criekinge, 2010; Paoletti, 2011; Reslow, 2012).

The contribution of this paper is two-fold. Taking the case studies of Senegal and Ghana, two countries targeted by the EU's external migration agenda, I first address the 'black box' of preference formation among domestic political actors, looking at internal institutional influences rather than external incentives. Political actors in policyreceiving countries may extract their legitimacy externally to the domestic sphere, or cooperate in exchange for material incentives. This premise has formed the basis of the EU's 'more for more' approach with third countries, which has typically used conditionality as a means of encouraging cooperation: accordingly, development aid financing, and visa facilitation, has hinged on third countries' willingness to readmit their nationals found in an irregular situation (Adepoju, van Noorloos, \& Zoomers, 2010; Carrera, Cassarino, El Qadim, Lahlou, \& den Hertog, 2016; Den Hertog, 2016). Yet this article proposes that actors respond to incentives and constraints at the domestic level in equal or greater part than they respond to the EU's migration governance approach. Policy actors perceive socioeconomic and political costs to the EU's migration policy proposals and are subject to considerations and constraints that stem from party politics, electoral pressures, media attention, public opinion and diaspora influence, where these factors both shape and constrain action. It is furthermore shown that domestic actors form sophisticated strategies to contest the EU's externalisation. Such contestation strategies emerge from longer-term experience with EU cooperation, 
whereby policy-recipient states who have experience in negotiations with the EU may fare better than negotiation 'newcomers' such as Niger (Koch, Weber, \& Werenfels, 2018). Secondly, this paper uses an organisational perspective to explore how domestic actors seek to increase institutional legitimacy and capacities, and to guard competence over migration issues. African government ministries, departments and agencies have mandates and migration policy preferences that may differ not only with those of the EU, but also internally. Cooperation also takes place over the long-term whereas domestic political or organisational changes can cause a top-down reprioritisation of policy interests and tasks, a distancing from previous policies, or a change of actors all of which have an impact on cooperation dynamics. Organisational dynamics within Senegalese and Ghanaian government ministries are thus shown to have an effect on achieving meaningful cooperation with the EU.

In proceeding, this paper addresses a geographical research gap. While sub-Saharan African countries feature increasingly prominently on the EU's external migration agenda following recently introduced EU policies, frameworks and instruments that target sub-Saharan Africa and the West African region in particular, the bulk of existing literature is on the EU 'neighbourhood' of North Africa (see Cassarino, 2014; De Haas, 2008a; El Qadim, 2014; Paoletti, 2011) and Central/Eastern Europe when assessing the impact of EU external governance in third countries. In the West African context, empirical research on migration governance and policy formulation remains limited - exceptions include Adam, Trauner, Jegen, and Roos (2019); Andersson (2014); Chou and Gibert (2012); Frowd (2018); Trauner and Deimel (2013). This paper complements these and other studies while offering a differentiated account of the preference formation of domestic actors in Senegal and Ghana.

\section{Methodology}

The analysis presented draws on research conducted in Brussels, Dakar and Accra between September 2017 and March 2018. Thirty-one semi-structured interviews were conducted with officials working at the EU Delegations in Dakar and Accra; Senegalese and Ghanaian government officials working in ministries or government agencies dealing with migration; EU project implementers (both in field offices and in Brussels); and Senegalese and Ghanaian epistemic communities. Interviewees were selected against the criteria of being involved in an aspect of migration policy in their day-today jobs. A central aim of the selection process was to have a representation of viewpoints from the key government ministries who deal with migration (the Ministry of Interior and the Ministry of Foreign Affairs) but to also gather perspectives from wider policy communities: other migration policy researchers or practitioners whose role is more commonly overlooked in the existing literature, as a focus on security and law enforcement (and actors involved therein) often prevails. ${ }^{3}$ As such, efforts were made to secure interviews with civil servants at other ministries dealing with aspects of migration, migration scholars in Senegal and Ghana, and government-contracted consultants. Interviews were conducted in English or French and were recorded and transcribed - when recording was not possible, notes were taken during the interview.

${ }^{3}$ I employ the term 'policy community' in the same sense as Kingdon (2014): a community composed of specialists in a policy area, 'scattered both through and outside of government' (p.117) including government ministerial and agency officials but also academics, consultants and analysts for interest groups. 
Other interviews were conducted as part of my wider $\mathrm{PhD}$ research with civil society organisations, European Commission officials, EU Member State government officials, and migrant association representatives, and are not directly included here, although they have informed my analysis from a broader perspective.

To gain access to Senegalese and Ghanaian government officials, it was necessary to request formal top-down permission to conduct research within the government ministries. The use of an introduction letter detailing my research aims and featuring a link to my departmental profile at my university enabled me to gain access to initial points of contact as well as my first interviewees, who would then introduce me to other research participants within the ministry or agency. Appointments with officials in Dakar and Accra were secured primarily by phone and frequently with the assistance of secretarial and support staff, with emails being notably more likely to fail to deliver or to be ignored. For interviews conducted in Brussels, email generally proved effective as a means of securing participation. Interviews were transcribed and subsequently coded using qualitative analysis software Atlas Ti. A thematic coding analysis approach (Robson \& McCartan, 2016, pp.467-470) was used inductively: codes were not pre-determined but generated directly from the data in an initial round of coding, with codes revised and grouped into a smaller number of themes in secondary coding. The software's 'network' function was used as a tool to map and visualise patterns, themes and trends in the data, and to aid analysis. The analysis also draws on documentary research and on my participation as an observer in migration stakeholder workshops, including civil society workshops and consultations between government and civil society in Senegal and Ghana. Documents used in the analysis of this paper include both National Migration Policy (NMP) documents, where Ghana's NMP is available online and the Senegalese NMP document was obtained from the Senegalese Ministry of Finance.

The selection of two West African countries as case studies in this research is useful because the EU's ability to attain its policy preferences in cooperation in this context is more limited: accession conditionality has proven a strong incentive for cooperation (Lavenex \& Schimmelfennig, 2009) but is absent as a bargaining 'carrot' in the case of the EU's cooperation with African states. The case study selection also mirrors the EU's selection of West Africa as a target region for enhanced partnership in migration. The strategic importance of Senegal as a partner in the region is acknowledged by the European Commission and is demonstrated in recent policy developments which include the selection of Senegal as one of five 'compact' countries (enhanced EU-third country partnership framework in migration); the recent historical efforts in targeting the Senegalese government for the signing of a Mobility Partnership; and the status the African nation enjoys as one of the main beneficiaries of the EU Emergency Trust Fund for Africa since its introduction in late 2015. Ghana makes up part of the smaller, second wave of African countries to become eligible for financing under the EU Trust Fund, which it became eligible for in June 2017. Ghana's access to the Trust Fund, until recently, remained more indirect than Senegal's - while initially it could only access funding for projects implemented in the wider region, since 2019 it is eligible for national projects. Both Senegal and Ghana are longstanding partners of the EU and EU Member States in migration as evidenced by several programmes that have run 
in each country over a long term, suggesting they each have a certain amount of experience in negotiating with European counterparts in this area.

\section{Historical overview and key state actors}

While statistics on migration flows should be treated with caution, it has been shown that both Senegal and Ghana are among the largest contributors of migratory flows to Europe, next to Nigeria (De Haas, 2008b). In addition, both countries have a history as migrant-receiving nations in the region. In the case of Senegal, the fall in the global price of groundnut oil altered the country from an immigration to an emigration nation after 1975 (Cross, 2013) while remittances from Senegalese migrants abroad gained in importance in light of the 1994 devaluation of the CFA franc, and the collapse of agricultural sectors (Cross, 2013). Despite the gradual closure of European borders and the enforcement of entry visas into France as of 1985 and Italy as of 1990, many Senegalese continued to emigrate.

In the case of Ghana, the country's relative affluence after its independence in 1957 ensured that it remained an attractive place for migrants: in particular, the development of industry induced both rural to urban internal migration as well as sub-regional migration to Ghana's urban centres (Awumbila, Manuh, Quartey, Tagoe, \& Bosiakoh, 2008, p.7). Similarly to Senegal, emigration picked up in the 1970s and 1980s following an economic downturn, and migration thereafter emerged as a strategy for dealing with economic and social challenges in the home country. At the same time, it should be stressed that around 70\% of Ghana's international migrants reside in other ECOWAS (Economic Community of West African States) Member States (Devillard, Bacchi, \& Noack, 2015, p.165) with migration to OECD countries a comparatively small phenomenon.

\section{Senegal}

Of the Senegalese government ministries involved in migration policy, interviews were conducted with the Ministry of Interior's Air and Border Police (DPAF), the Ministry of Foreign Affairs and Senegalese Abroad (MAESE), the Directorate-General for Senegalese Abroad (DGSE) and the Directorate-General for Human Capital (DDCH) under the Ministry of Finance.

The Senegalese Ministry of Foreign Affairs now includes the DGSE from what was formerly a separate ministry. It is the DGSE that acts as the project implementing arm of the Ministry of Foreign Affairs, while it is the political unit of the ministry that conducts diplomatic discussions with other countries on migration and that deals with more sensitive issues that arise, such as returns. The Senegalese Ministry of Interior has a long-standing collaboration with the EU and Frontex (the European Border and Coast Guard Agency) where this collaboration was formed with the intention of eliminating irregular migration from the Senegalese coastline. This has been 'successful' in the sense that no departures now take place from Senegalese shores, although migration routes have merely shifted to other shores and to land routes. MAESE is also primarily involved in managing the rights of the Senegalese diaspora abroad and promoting their interests, together with the DGSE. Other ministries are involved in 
different aspects of migration policy. The DDCH has been placed in charge of coordinating the production of Senegal's NMP.

\section{Ghana}

Of the Ghanaian government ministries involved in migration policy, interviews were conducted with the Ministry of Interior and the Ghana Immigration Service (GIS) (a government agency under the umbrella of the Ministry of Interior); the Ministry of Foreign Affairs and Regional Integration (MoFARI); the Ministry of Employment and Labour Relations; and the Ministry of Justice (Attorney-General's Office).

Competency for migration issues is, as with the Senegalese government, spread between different ministries, government departments and agencies. Within MoFARI, efforts are aimed at maintaining good bilateral relations, and ensuring that policies are well 'meted out.' In practice, this means ensuring that the 'comprehensive' approach as espoused by the EU does indeed encompass the five pillars agreed upon at the 2015 Valletta Summit, and does not focus solely on returns and readmissions. The Multilateral Relations Bureau at MoFARI promotes the humane treatment of migrants and seeks to ensure that benefits of migration to both sending and receiving countries are harnessed. The Ministry of Justice deals with legal aspects of migration policy, including advising on treaties and ensuring their alignment with existing protocols and laws at the national and regional (ECOWAS) level. It is the Ministry of Interior that has a longstanding collaboration with the EU and EU Member States in managing migration, and has received substantial funding by the EU in support of capacity building of its institutions. This is most notable in the continued stream of financing to the GIS, which has seen the increase in size of its anti-trafficking unit; the establishment of the Migration Information Bureau within GIS (an idea initially proposed by the UK government through the EU and readily accepted by GIS); several flagship projects in building border management capacity such as the Ghana Integrated Migration Management Approach, which set up a Migration Information Centre in the north Ghanaian transit town of Sunyani. ${ }^{5}$ The significant investment by the EU in favour of GIS, and migration management activities, is noted by other ministries, who perceive the EU's preference in this direction. ${ }^{6}$

\section{Preference formation: returns and readmission}

A key aim of the EU and EU Member States has long been the securement of migrant readmission agreements with third countries, and as a result this has formed a core part of the EU's migration dialogue with many African countries. The importance accorded by the EU to securing a higher rate of return is reasserted in the 2016 Partnership Framework where it is expressly stated that the 'paramount priority is to achieve fast and operational returns' whether through formal readmission agreements or other - informal - arrangements (European Commission, 2016, p.7). Despite past EU and EU Member State efforts, there has been little progress in securing readmission agreements with African states. Readmission agreements remain a largely unpopular political choice for state actors in Senegal and Ghana, for reasons discussed in this section; yet,

\footnotetext{
${ }^{4}$ Interview with senior official at MoFARI, Europe Bureau, Accra. 23 February 2018.

${ }^{5}$ Interview at GIS, Accra, 9 March 2018.

${ }^{6}$ Interview with EU Desk Officer at MoFARI, Accra, 23 February 2018.
} 
returns do take place and policymakers are not averse to returns in all cases. There is therefore a need to theorise in more detail the preferences of actors. The graphs below detail the total number of return orders issued by EU Member States to presumed Senegalese and Ghanaian irregular migrants in the years 2011-2018 (Fig. 1) and the percentage of these return orders carried out (Fig. 2). Senegalese migrants have been the subject of return orders in greater numbers than Ghanaians. The rate of return has remained fairly constant, with the percentage of return orders carried out varying between 8 and $15 \%$ for Senegal, and a slightly higher rate of $18-34 \%$ for Ghana.

\section{Socioeconomic and political costs}

\section{Remittances and reintegration}

While encouraging the return of the diaspora to contribute to national development has formed a part of government migration policy in both countries, Senegalese and Ghanaian state actors are reluctant to accept 'involuntary' returns and readmission for political reasons, while also considering the domestic socioeconomic implications.

From an economic perspective, the cost of accepting involuntary (or 'forced') returns is twofold. The first constitutes the immediate loss of remittances, while remittances make up an important part of GDP in both Senegal and Ghana. The 'economic weight' of Senegalese abroad is, for instance, considered more important to the Senegalese state than external (development) aid. ${ }^{7}$ Many households depend on migrant remittances for daily expenses, where a Senegalese DGSE official observed that if emigrants did not remit, it would be 'a disaster'. ${ }^{8}$ The secondary economic impact stems from challenges in reintegrating returnees. Presently, neither Senegal nor Ghana has the capacity to adequately reintegrate returnees. The Senegalese NMP notes the lack of a national mechanism to deal with 'involuntary returns' with regard to the distinct needs of forcibly returned migrants, which includes psychological, social, legal and financial support (Senegalese NMP: Ministry of Finance of Senegal, 2018). Ghanaian officials equally note the 'abrupt return' of Ghanaians between 2011 and 2012 posed 'significant challenges' regarding reintegration (Ghanaian NMP: Ministry of Interior of Ghana, 2016, p.44). The abrupt nature of forced returns removes the agency migrants have regarding the timing of their return journey. Studies on return migration and development have largely shown that migrants need time to save while abroad in order to build a house or start a business on their return or they are more likely to become dependent on family members (Åkesson, 2011; Cross, 2013). Returnees who do not reintegrate socially and economically are likely to become a burden to the state, where a Ghanaian official from the Bureau of Diaspora Affairs cited unemployment and increasing crime rates as consequences that would need to be managed by the state. ${ }^{9}$

State mechanisms to support returnees, to the extent that these exist, focus largely on voluntary returns - such as the Fonds d'Appui à l'Investissement des Sénégalais de l'Extérieur programme in Senegal, where eligibility to accessing project funding is limited to Senegalese abroad who have a legal immigration status in their host country, and who can demonstrate business acumen (see MAESE, 2016). This chimes with broader findings in the literature that African states' diaspora policy tends to profile the

\footnotetext{
${ }^{7}$ Interview at EU Delegation, Dakar, 13 October 2017.

${ }^{8}$ Interview at DGSE, Dakar, 17 October 2017.

${ }^{9}$ Interview at Diaspora Bureau, Office of the President, 20 February 2018.
} 


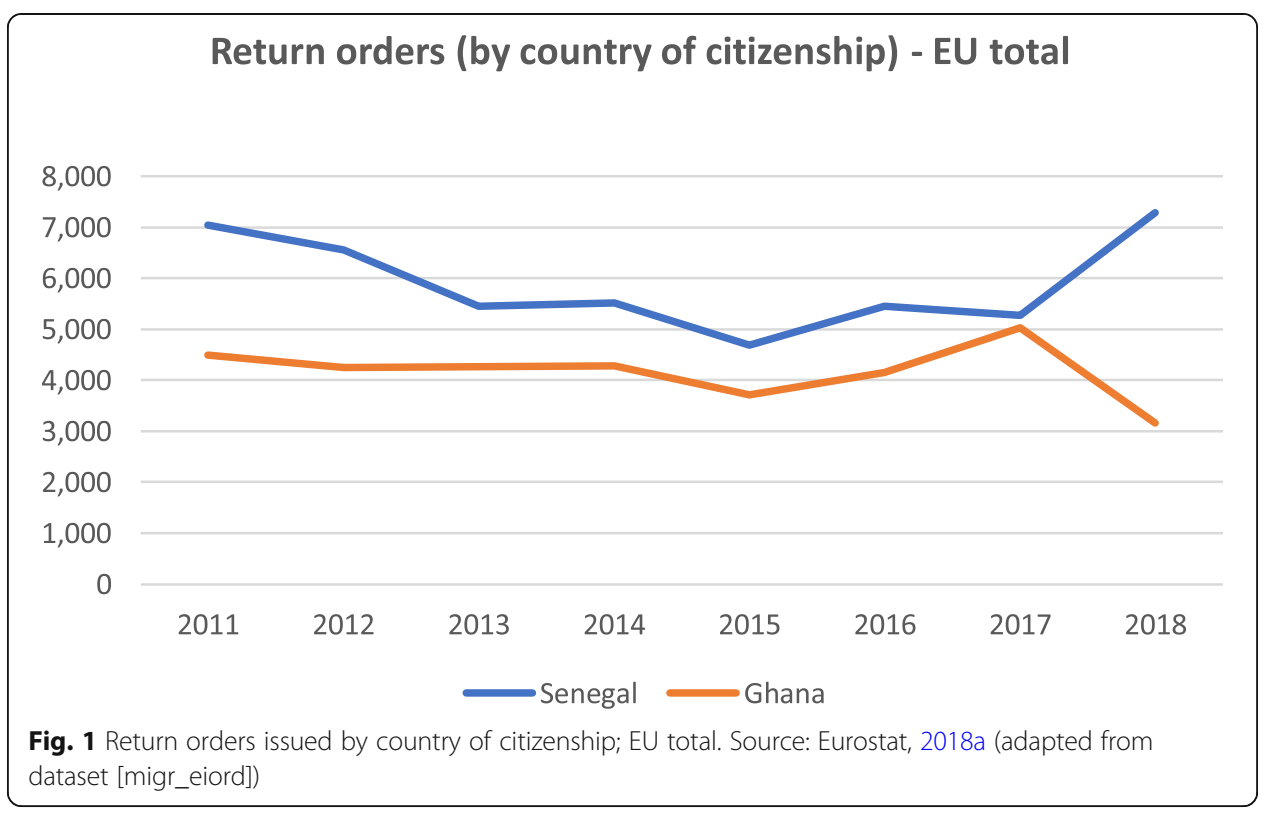

'ideal migrant returnee' as resourceful, experienced and entrepreneurial (Sinatti, 2018, p.2; Naudé, Siegel, \& Marchand, 2017). Migrants who are forcibly returned do not necessarily reflect this profile, and as such state reintegration mechanisms are currently poorly matched with the specific needs of forced returnees. The Senegalese state has, since the 1980s, also operated Bureaux d'Accueil et d'Orientation des Sénégalais de l'Extérieur (BAOS) which are offices intended to provide information and advice to returnees, including guiding returnees towards funding opportunities. Yet, the BAOS remain understaffed and underfunded, as noted by the Senegalese NMP (Ministry of Finance of Senegal, 2018, p.88). Civil society organisations working with returnees have observed that returnees are also largely unaware of the existence of these support

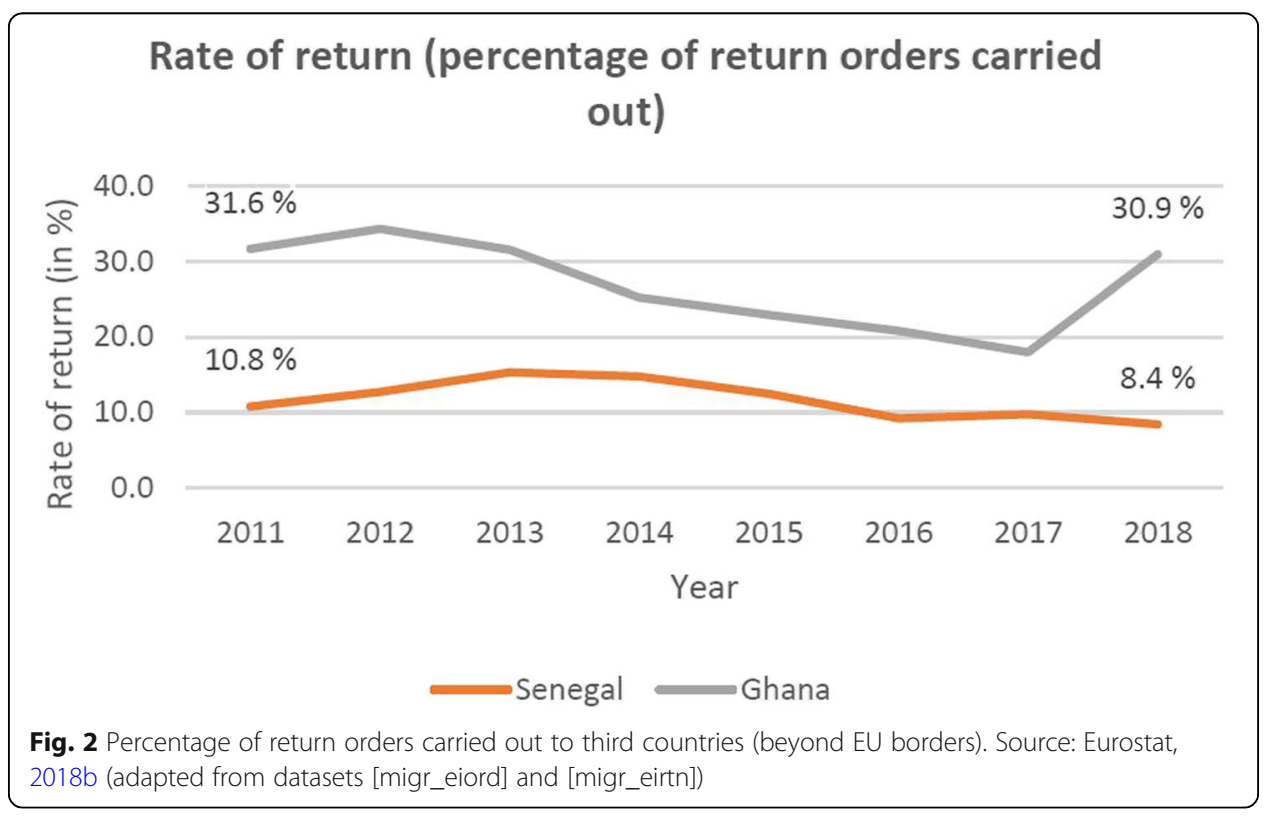


mechanisms. Despite the increased politicisation surrounding returns and the increase in the overall number of return programmes since 2005, return migration has been little studied or systematically analysed by policymakers, where this research gap is particularly noticeable in the African context (Black \& King, 2004; Flahaux \& Kabbanji, 2013; Ghosh, 2000). This adds to the uncertainty of managing return and reintegration in a way that effectively mediates negative social externalities. EU countries have policies regarding provisions for reintegration support that vary widely - some are viewed more favourably, such as in the case of Swiss-Senegalese cooperation on returns and reintegration implemented by the DGSE, which is cited as a preferred model for cooperation on return by MAESE's diplomatic branch. ${ }^{10}$ An interviewee at the Ghanaian MoFARI also observed that the EUTF has since recently ensured Ghanaian deportees are given a stipend towards their reintegration. ${ }^{11}$ Since 2017, the EUTF has implemented projects in Senegal and Ghana which provide funds for reintegrating returnees (see e.g. European Commission, 2017).

\section{Public opinion}

State actors are equally wary of negative public opinion, where media scrutiny surrounding returns disincentivises cooperation on returns with European countries. On the one hand, this has led to more informal cooperation on returns in the form of 'non-standard' arrangements in place of formal agreements that are less visible to both the European and African public (Cassarino, 2007). Both Senegal and Ghana are democratic states, ensuring political actors are cautious when dealing with contentious issues, given the possibility rival political parties will make use of negative public sentiment in election campaigns. Citing political ramifications, a senior official at the Migration Unit of the Ministry of Interior of Ghana noted that public opinion determined the ministry's unwillingness to be seen to be cooperating with the EU regarding identification missions to facilitate returns. ${ }^{12}$ In both countries the relationship between policy communities and the media on the topic of migration is strained. There is a perception among both state and non-state policy actors that journalists demonstrate a poor grasp of migration concepts that affects reporting quality on migration issues, with a tendency to reproduce news stories and media narratives from Northern countries with little or no added analytical scrutiny or context. ${ }^{13}$ Policy communities in both countries have sought to address this by providing training to journalists in the hope to sensitise the media on various aspects of migration issues, and to encourage more favourable and objective reporting.

In addition to voters at home, the diaspora also constitute an increasingly powerful voice in state affairs and governance. In Senegal, a legislative change took place in 2017 whereby 15 additional seats were added to the National Assembly, earmarked for members of the diaspora. This has made the country a relative exception in the region, as few other African states have facilitated the political empowerment of their diaspora through direct parliamentary representation. Although the diaspora represent less than $5 \%$ of the electorate, Senegalese political parties run election campaigns advancing propositions that cater to the

\footnotetext{
${ }^{10}$ Interview at MAESE, Dakar, 10 November 2017.

${ }^{11}$ Interview, MoFARI, Europe Desk, Accra, 23 February 2018.

${ }^{12}$ Interview at Ministry of Interior, Accra, 23 February 2018.

${ }^{13}$ Interview at CMS, University of Ghana, Accra, 20 February 2018.
} 
diaspora; the Senegalese diaspora are also perceived as 'grands électeurs' (influential voters) to the extent that they are considered to influence voting behaviour at home (Maillard \& Costard, 2019). The 2019 national elections in Senegal saw a shift in the national political debate as the pan-African and sovereignist discourse of candidate Ousmane Sonko proved broadly appealing but resonated particularly strongly with the diaspora and young Senegalese voters (Niang \& Tandia, 2019). This signals that the Senegalese diaspora's influence in the country is not only economic in terms of remittances, but also distinctly political. ${ }^{14}$ While Ghanaian legislation has not extended to direct political representation, a dynamic that can be identified as of early 2017 is that the current government administration in Ghana consists of a significant number of former members of the diaspora. These former members of the Ghanaian diaspora had historically made both financial and 'political contributions' to the national political debate, from abroad, where the returnees in the current government hold key positions in Cabinet and as ministerial directors. ${ }^{15}$ Ghana has perhaps outpaced Senegal and indeed other African states in the scale of its charm offensive towards its diaspora, with the introduction of a number of policies that extend rights to the diaspora (such as the 'Right of Abode' law). Political parties have also set up branches in many host countries to engage with the diaspora - and to facilitate their involvement in Ghana's political development (Teye, Alhassan, \& Setrana, 2017, p.151). As Ghanaian and Senegalese political parties increasingly look to engage their diaspora for economic and political reasons, this is likely to be at odds with expanding cooperation with the $\mathrm{EU}$ on returns and readmission.

\section{Returns as inappropriate}

The relative domestic factors that come into play are therefore multi-faceted and considerable. At the same time, state actors perceive the EU's approach regarding returns and readmissions as inappropriate. This relates to two contentions in particular: a conflicting perspective on the appropriateness of implementing returns; and the issue of state sovereignty, where this has crystallised on the issue of identifications.

Senegalese and Ghanaian Foreign Affairs officials have sought to counter aspects of the EU's migration narrative and have argued for a different understanding on migration and returns in the following ways. Firstly, there is a desire among policymakers in both case studies to have the contributions of migrants in host countries acknowledged, and a recognition in EU-African migration dialogues that migration brings benefits to origin and host countries alike. Migration is also construed, by Ghanaian and Senegalese policymakers, as a phenomenon linked to globalisation. Although noting that 'nobody encourages irregular migration', an official at the Ghanaian MoFARI stressed that migration could hardly be curbed altogether as it is a 'human' phenomenon; and that this position is frequently adopted as a countering narrative by both the African Union and ECOWAS. ${ }^{16}$ Senegalese and Ghanaian policymakers furthermore point to the low number of visas as being a major driver of the decision to migrate irregularly. It is felt that an integral part of reducing irregular migration is a corresponding increase in legal pathways, and the need for the EU to facilitate a system of what one DGSE official dubbed 'organised immigration'. ${ }^{17}$ This is true even for

\footnotetext{
${ }^{14}$ Interview at EU Delegation, Dakar, 13 October 2017; Interview at DGSE, Dakar, 3 November 2017.

${ }^{15}$ Interview at Diaspora Bureau, Accra, 20 February 2018.

${ }^{16}$ Interview, MoFARI, Europe Desk, Accra, 23 February 2018.
} 
student visas and visas for business, which were perceived as being 'deplorably' low in 2015/2016. ${ }^{18}$

Beyond conflicting migration narratives, a point of serious contention with domestic rules is the identification procedures of assumed Senegalese or Ghanaian migrants. Despite repeated efforts on the part of the EU, MAESE has not signed an agreement with the EU which would expand cooperation on returns. Senegalese diplomatic officials perceive the return of migrants without the explicit involvement of the Senegalese state in confirming citizenship as unlawful, where MAESE considers identification of Senegalese abroad an area of its own jurisdiction, to be conducted against its own criteria. ${ }^{19}$ Failing this, one issue cited is the risk of false identifications resulting in persons of non-Senegalese citizenship being returned to Senegal. ${ }^{20}$ The use by some EU Member States of charter flights instead of commercial flights as a method of return is also strongly contested and viewed as unequivocally dehumanising. ${ }^{21}$ The question of sovereignty emerges in relation to the use of 'laissez passer' by EU Member States to return migrants: the Senegalese government determines that only 'sauf conduits' issued by MAESE, following case-by-case identification missions, are legally acceptable. $^{22}$ DPAF, as part of the Ministry of Interior of Senegal, also cites sovereignty infringement in explaining its policy of refusing entry to migrants returned with a European laissezpasser. $^{23}$ These points of contestation have provided a framework for the Senegalese government to limit cooperation on returns. MAESE's response to EU pressure to accept returns has been to fall back on 'classical mechanisms of cooperation' such as diplomacy, and where possible to reference applicable legal frameworks.

The questions of returns and readmission of migrants to Ghana is, as with Senegal, a contentious issue, although interviewees were less likely to cite sovereignty infringement as the key issue. Rather, reference was made primarily to public perceptions as a constraint in cooperating openly on returns. In April 2016, the Ghanaian MoFARI and Ministry of Interior signed a Joint Declaration with EU counterparts, with Ghana signifying its willingness to expand cooperation in the matter of returns of Ghanaian citizens of irregular status in the EU (EEAS, 2016). This was prompted by the EU's dissatisfaction with the return rate of Ghanaian irregular migrants (EEAS, 2016). While the data on returns carried out (see Fig. 2) since the signing of the agreement is far from conclusive given the short timeframe, there is as of yet no indication that the agreement has expanded cooperation on returns. Although a spike in the return rate can be observed for Ghana in 2017-2018 (Fig. 2), this should be interpreted in the context of a corresponding drop in the number of return orders issued in the same year. The Ghanaian MoFARI considers that returns should be optional, not forced, in all cases. $^{24}$ The question of both the limited number of visas for Ghanaians, and readmission cooperation, has brought the EU-Ghana political dialogue on migration to a halt: an interviewee from the EU Delegation in Accra commented that the finding of 'another framework' might be necessary, or for the EU Member States to push for readmissions agreements bilaterally rather than through the $\mathrm{EU}^{25}$

\footnotetext{
${ }^{17}$ Interviews at DGSE, Dakar, November 2017.

${ }^{18}$ Interviews at DGSE, Dakar, November 2017.

${ }^{19}$ Interviews at MAESE, Dakar, October-November 2017.

${ }^{20}$ Interview, MAESE, Dakar, 10 November 2017.

${ }^{21}$ Interviews at MAESE, Dakar, November 2017.

${ }^{22}$ Interview, MAESE, Dakar, 2 November 2017.

${ }^{23}$ Interview, DPAF, Dakar, 3 November 2017.

${ }^{24}$ Interview at Diaspora Bureau, Accra, 20 February 2018.
} 


\section{Exceptions - facilitating return}

Where either government has stated a willingness to facilitate returns this has been done primarily in the context of taking the humanitarian route when other intermediate political options have failed. In particular, interviewees in the Senegalese and Ghanaian ministries have noted that the reporting by the local media on the conditions of sub-Saharan African migrants in Libya acted as a catalyst in spurring ministerial action in repatriating migrants from Libya. In such cases, repatriation is viewed as the appropriate and humanitarian course of action when the plight of Senegalese and Ghanaian migrants in Libya is in the media spotlight, and where inaction would detract from state actors' legitimacy. The EU's cooperation with Senegal and Ghana in the case of 'assisted voluntary returns' along the migration route has therefore, in contrast to returns from Europe, been largely successful, although the number of returns in question is of a smaller scale.

Equally, in its bilateral relations with France, Senegal has a comprehensive bilateral agreement that includes readmission but also facilitation of entry for Senegalese into the French labour market. In the case of this particular agreement, MAESE agrees in principle to cooperate in the return of irregular migrants from France. However, it pursues this avenue only when 'intermediate political options' have been exhausted. ${ }^{26}$ The agreement bestows on the Senegalese government leeway in negotiating returns and raising objections, where under pre-determined circumstances a detained Senegalese migrant can still claim exceptional leave to stay. In some cases, MAESE was able to negotiate regularisation as an alternative option. If negotiations for such intermediate options fail, returns are accepted as the appropriate humanitarian course of action.

\section{Impact on cooperation}

Party politics

In both case studies, state actors have a varying interest and commitment to migration policies, and the pursuit of specific migration policy options is partly attributable to domestic party politics and its dynamics.

Both countries have been the recipients of external funding to put in place migration policy frameworks. In the case of Ghana, the NMP was launched in April 2016. The Ghanaian Ministry of Interior - the 'owner' of the NMP - opted to outsource the drafting of this policy to key external partners, in particular consultants at the Centre for Migration Studies at the University of Ghana, and with oversight from the International Organization for Migration (IOM). From the NMP the need to establish a Diaspora Engagement Policy was identified, as well as a Labour Migration Policy. However, political developments in Ghana have effectively impeded the rolling out of the NMP. With the election of a new government, the policy has seen little to no advancement in actual implementation. Interviewees point to the current government's desire to revisit and re-evaluate the NMP, and that as a result the document has been shelved. ${ }^{27}$ One of the key bodies set out in the document to oversee the implementation of the Policy - the Ghana National Commission on Migration - has not taken form. The reasons for this include the shifting political context and the distancing of the new party in power to the activities of the previous party; at the same time, several actors have also noted the need for renewed external funding. ${ }^{28}$

\footnotetext{
${ }^{25}$ Interview at EU Delegation, Accra, 25 January 2018.

${ }^{26}$ Interviews at MAESE, and DGSE, Dakar, October-November 2017.

${ }^{27}$ Interviews at EU Delegation, Accra, 25 January 2018; and Diaspora Bureau, Accra, 20 February 2018.
} 
While it can be reasonably expected that the increased representation of members of the Ghanaian diaspora in key positions of government will make the current government receptive to efforts to safeguard the rights of Ghanaians abroad - and to encourage the investments of diaspora in Ghana's national development - so far such developments have not materialised. The Diaspora Engagement Policy remains unimplemented following the same logic that the document is largely associated with the activities and priorities of the previous Ghanaian government. The decision to migrate the Diaspora Bureau - formerly under MoFARI - to the Office of the President has also effectively resulted in the drastic shrinking of the Diaspora Bureau, as a number of staff were relocated to other ministerial areas and departments, and thus resulting in the loss of expertise and institutional memory in this area. ${ }^{29}$

In Senegal, the current government's discourse on the notion of 'terre ferme' ('solid ground'), which addresses the challenge of youth unemployment by supporting agricultural activities in economically depressed regions, has found substantial common ground with the EU's approach of addressing the 'root causes' of irregular migration in migrant departure zones. ${ }^{30}$ This has led to several EUTF interventions in Senegal focusing on agriculture. Yet, civil society actors have been more pessimistic about this political agenda when noting that the ongoing focus on agriculture is both misplaced in relation to aspirations of the youth, and unpromising in terms of the country's future economic development. ${ }^{31}$

\section{Inter-ministerial dynamics}

One important feature of inter-ministerial dynamics that emerges is that they are characterised by the pursuit of goals along individual ministerial lines. This is further compounded by the lack of formalised and regular inter-ministerial interactions between the ministries working on migration. There is often no singular ministry that is considered the lead ministry in migration matters. The slow progress of the drafting of the Senegalese NMP, which began in July 2015 and was publicised in the Senegalese media as having been launched in March 2018, is in part attributed to a lack of communication. ${ }^{32}$ The NMP's delayed production has been deplored by civil society actors who raise the possibility of the document no longer being timely or relevant. The Ministry of Finance has yet to obtain the necessary 'political stamp' of approval for the policy from the overseeing inter-ministerial council, an indication that the policy remains in political limbo. ${ }^{33}$

While there is no official key ministry or government agency that maintains an oversight of migration policy in Senegal, the DGSE emerges as a key interlocutor for several external actors - and is perceived by these actors as the more appropriate coordinating government body. An EU Delegation interviewee commented that while interactions with Senegalese ministries followed thematic and technical lines, mirroring areas of project interventions and dealing with the relevant ministry where appropriate, the

\footnotetext{
${ }^{28}$ Interviews at: Ministry of Employment and Labour Relations, Accra, 9 March 2018; Ministry of Interior Migration Unit, Accra, 23 February 2018; Ministry of Justice, Accra, 2 March 2018.

${ }^{29}$ Interview at CMS, University of Ghana, Accra, 20 February 2018.

${ }^{30}$ Interview at MAESE, Dakar, 2 November 2017.

${ }^{31}$ Notes from government-civil society stakeholder meeting, November 2017.

${ }^{32}$ Notes from government-civil society stakeholder meeting, November 2017.

${ }^{33}$ Personal e-mail communication, DDCH official, 3 October 2018.
} 
'transversal interlocutor' is the DGSE. ${ }^{34}$ The DGSE is seen to have a more comprehensive and cross-cutting view on migration issues, given its focus on Senegalese abroad and accordingly the matter of migrant returns, and the fact that migrant return remains an objective common to all EU projects. ${ }^{35}$ The IOM in Dakar has equally called on the DGSE to take the lead in organising inter-organisational consultations between both state and external actors working on migration policy and projects in Senegal. ${ }^{36}$

This lack of inter-ministerial communication is highlighted by both external and internal actors. An interviewee from the $\mathrm{DDCH}$, in relation to the development of the NMP, commented on the difficulties of promoting a consensual and common vision on migration between government stakeholders; and the challenges that arise from each ministry pursuing a migration agenda in relation to its own institutional priorities. This was indicative of competition between ministries seeking to exert their influence. An IOM interviewee in Dakar cited the following example: while MAESE lodged a technical assistance request and commenced activities, it became apparent that the project requested necessitated dealing with legal aspects that fall under the responsibility of the Ministry of Justice, whereas this ministry had so far been excluded from all involvement in the project. ${ }^{37}$ With no process for formal consultation between the two ministries existing, a meeting between the two ministries was thus set up externally by the IOM to facilitate coordination.

Inter-ministerial competition and ad-hoc coordination is equally present in Ghana and is noted by both internal and external actors. An interviewee at the EU Delegation commented on the difficulties of getting ministries together, and of the competition between the Ministry of Interior and the Ministry of Foreign Affairs in the matter of competence with regard to identification missions of Ghanaian nationals. ${ }^{38}$ The GIS (under the Ministry of Interior) is tasked with accompanying MoFARI and consulate officials on identification missions, but coordination issues have sparked tensions between the two ministerial entities. ${ }^{39}$

The Ghanaian Ministry of Justice deals with legal aspects of migration policy and advises other ministries on aspects of national and regional law that affect their activities, including the signing of bilateral or international agreements. However, an interviewee spoke of the apparent side-lining of the Attorney-General's Office in migration matters pertaining to the ministry's area of expertise. Even in cases where the ministry was consulted, this would frequently only occur retroactively whereas earlier consultations and advice-seeking could have circumvented difficulties that arose.

\section{Capacity-building along ministerial lines}

The tendency of the EU and EU Member States to pursue working relationships with individual ministries has furthered the opportunities for ministries to reinforce their mandates, bolster their own instititutional capacities in migration, and extend their activities across different thematic areas. Project implementers have noted that the increase in available migration programmes and funding has enabled ministries to

\footnotetext{
${ }^{34}$ Interview at EU Delegation, Dakar, 7 November 2017.

${ }^{35}$ Interview at EU Delegation, Dakar, 13 October 2017.

${ }^{36}$ Interview at IOM, Dakar, 17 October 2017.

${ }^{37}$ Interview (Skype) with IOM, Dakar, 11 December 2017.

${ }^{38}$ Interview at EU Delegation, Accra, 25 January 2018.

${ }^{39}$ Interview at EU Delegation, Accra, 25 January 2018.
} 
cherry-pick programmes according to their own preferences, choosing implementation partners and programme frameworks accordingly. State actors of different countries find that they can access a range of funding options for migration programmes. Particularly West and Central African countries are presented with a 'massive' number of initiatives from the EU, each representing particular political or regional perspectives: in practice, individual countries have access to different possibilities whereby 'knocking on the door of [an] action, if there is a refusal, they will go to another one'. ${ }^{40}$

In one instance, a migration technical assistance programme under the International Centre for Migration Policy Development (ICMPD) received a request from the Ghanaian Bureau of Diaspora Affairs (at the time under the Ghanaian MoFARI) to assist in the formulation of a Diaspora Engagement Policy. The project was initiated but as other international actors came into play, MoFARI opted to discontinue cooperation with the ICMPD in favour of another partner organisation. In addition to apparent increased funding, the proposed framework of the new partner organisation better suited the Ghanaian MoFARI's preferences, that preferred to outsource the drafting of the policy to an external consultant rather than draft it internally (as the ICMPD project would have required). ${ }^{41}$ These instances demonstrate how Senegalese and Ghanaian political actors have capitalised on the proliferation of donor-funding for migration programmes to pursue sectorial or structural preferences.

\section{Organisational challenges}

A final recurring theme is the challenge of staff turnover within government ministries. This frequently results in the dismantling of inter-personal networks that further stunt both inter-ministerial communication and communication with external actors. Staff turnover and departmental reshuffling also entails the loss of expertise, as highlighted earlier within Ghana's Bureau of Diaspora Affairs. A key official of the Senegalese MAESE who attended the EU's Valletta Summit in late 2015 and who had been closely involved in the EU-Senegal political dialogue on migration following Valletta, had since relocated to South Africa for an embassy role. ${ }^{42}$ Project implementers also point to political commitment to a project or initiative being seen to disappear when civil service staff in the Ghanaian ministries move to a different role. ${ }^{43}$ In another case, the departure of a senior official from the Migration Information Centre of the Ghanaian Ministry of Interior resulted in the loss of progress in inter-ministerial communication, with the disappearance of a key facilitator. ${ }^{44}$ In many instances it is through externallyfacilitated meetings or workshops, such as those organised by the EU or the IOM, that inter-ministerial interaction on migration takes place.

\section{Conclusion}

This paper has set out to map the preferences and resulting strategies of policy actors in West Africa in response to the EU's external migration agenda, taking as a focal point the domestic conditions under which these actors operate. Throughout this paper

\footnotetext{
${ }^{40}$ Interview at IOM, Brussels, 27 September 2017.

${ }^{41}$ Interview at ICMPD, Brussels, 22 September 2017.

${ }^{42}$ Interview at DGSE, Dakar, 17 October 2017.

${ }^{43}$ Interview at ICMPD, Brussels, 22 September 2017.

${ }^{44}$ Interview at Ministry of Justice, Accra, 2 March 2018.
} 
I have argued that preference formation among domestic state actors in countries at the receiving end of the EU's migration policy proposals needs to be unpacked, given that state actors respond to domestic considerations in equal or in greater part than they respond to external incentives offered by the EU. This article has therefore taken as a starting point the need to look beyond the limits of EU external governance in explanations of migration policy cooperation outcomes with West African countries which has traditionally looked at constraints on EU institutional and political power as a source of empowerment for third countries in negotiations - and examine instead the intricacies of preference formation among African state actors as shaped by domestic institutions. Looking at cooperation on the topic of returns, this paper has identified the key contentions among domestic actors, which differed to some extent between Ghanaian and Senegalese policymakers. It also identified some of the institutional constraints they operate under, and the varying mechanisms used to act on policy preferences. Public opinion emerges as a strong constraining factor, where the role of the diaspora in shaping and constraining policymakers' responses to the EU's external migration agenda is touched upon in this article but could form an avenue for further research.

At the same time, this article has demonstrated that the outcome of policy formation and cooperation in the case studies is impacted by coordination issues and competition between political actors, who also seek to increase their institutional capacities, reinforce their mandate, and maintain or extend their competencies in migration policy. Cooperation outcomes and policies, even when formally agreed upon, are subject to domestic political or organisational shifts that can cause a top-down reprioritisation of policy aims and interests, a shelving of previously approved policies, or a change of actors - which are factors shown to have an impact on cooperation dynamics. Party politics, public opinion, the political and economic clout of the diaspora as well as organisational realities such as a high rate of staff turnover within Senegalese and Ghanaian ministries are thus shown to influence cooperation outcomes.

\begin{tabular}{lll} 
List of interviews & & \\
\hline Institution & Location & No. of interviews \\
Centre for Migration Studies, University of Ghana & Accra & 3 \\
EU Delegation to Ghana & Accra & 1 \\
GIS, Ministry of Interior of Ghana & Accra & 1 \\
Ministry of Employment and Labour Relations of Ghana & Accra & 1 \\
Ministry of Foreign Affairs and Regional Integration (MoFARI) of Ghana & Accra & 3 \\
Ministry of Interior of Ghana, Migration Unit & Accra & 1 \\
Ministry of Justice of Ghana, Attorney-General's Office & Accra & 1 \\
Diaspora Bureau, Office of the President of Ghana & Accra & 1 \\
EU Delegation to Senegal & Dakar & 3 \\
University of Cheikh Anta Diop & Dakar & 1 \\
Ministry of Foreign Affairs and Senegalese Abroad (MAESE) & Dakar & 4 \\
Directorate-General for Senegalese Abroad (DGSE) & Dakar & 3 \\
Air and Border Police (DPAF), Ministry of Interior of Senegal & Dakar & 1 \\
Directorate General for Human Capital (DDCH), Ministry of Finance of Senegal & Dakar & 1
\end{tabular}


List of interviews (Continued)

\begin{tabular}{lll}
\hline International Organization for Migration (IOM) in Senegal & Dakar & 2 \\
IOM in Ghana & Accra & 2 \\
IOM, Brussels office & Brussels & 1 \\
International Centre for Migration Policy Development & Brussels & 1 \\
\hline
\end{tabular}

\section{Abbreviations}

BAOS: Bureaux d'Accueil et d'Orientation des Sénégalais de l'Extérieur; DDCH: Directorate-General for Human Capital; DGSE: Directorate-General for Senegalese Abroad; ECOWAS: Economic Community of West African States; EUTF: EU Emergency Trust Fund for Africa; GDP: Gross Domestic Product; GIS: Ghana Immigration Service; ICMPD: International Centre for Migration Policy Development; IOM: International Organization for Migration; MAESE: Ministry of Foreign Affairs and Senegalese Abroad; MoFARI: Ministry of Foreign Affairs and Regional Integration; NMP: National Migration Policy; OECD: Organisation for Economic Cooperation and Development

\section{Acknowledgements}

The author thanks Alexandra Winkels, Christof Roos, James F. Hollifield, Lorena Gazzotti and the anonymous reviewers for their feedback and comments on earlier drafts of this article.

\section{Authors' contributions}

The author has read and approved the submitted manuscript.

\section{Funding}

This research has been funded by the Prins Bernhard Cultuurfonds, the Hendrik Muller fonds, the Department of Politics and International Studies at the University of Cambridge, the Smuts Memorial Fund, and the African Studies Centre at the University of Cambridge through a UAC of Nigeria Travel Fund. Further financial support from Lucy Cavendish College for conference participation, where an earlier iteration of this paper was presented, is gratefully acknowledged.

\section{Availability of data and materials}

The datasets generated and/or analysed during the current study are available in the Eurostat repository, http:// appsso.eurostat.ec.europa.eu/nui/show.do?dataset=migr_eiord and http://appsso.eurostat.ec.europa.eu/nui/show. do?dataset=migr_eirtn. Qualitative interview data and primary documents collected as part of my PhD. Not publicly available due to data protection issues.

\section{Competing interests}

The author declares that she has no competing interests.

Received: 15 October 2018 Accepted: 11 July 2019

\section{Published online: 26 August 2019}

\section{References}

Adam, I., Trauner, F. Jegen, L. \& Roos, C. (2019). West African Interests in (EU) Migration Policy (Policy Brief. UNU-CRIS, PB2019/4). Retrieved from http://cris.unu.edu/west-african-interests-eu-migration-policy.

Adepoju, A., van Noorloos, F., \& Zoomers, A. (2010). Europe's migration agreements with migrant-sending countries in the global south: A critical review. International Migration, 48(3), 42-75.

Åkesson, L. (2011). Making migrants responsible for development: Cape Verdean returnees and northern migration policies. Africa Spectrum, 46(1), 61-83.

Andersson, R. (2014). Illegality, Inc:: Clandestine migration and the business of bordering Europe. Oakland: University of California Press.

Aubarell, G., Zapata-Barrero, R., \& Aragall, X. (2009). New directions of national immigration policies: The development of the external dimension and its relationship with the Euro-Mediterranean process (EuroMESCO Paper No.79). Retrieved from https:/www.euromesco.net/wp-content/uploads/2017/10/200902-EuroMeSCo-Paper-1.79.pdf.

Awumbila, M., Manuh, T., Quartey, P., Tagoe, C., \& Bosiakoh, T. (2008). Migration country paper: Ghana. Retrieved from https:// www.imi-n.org/files/completed-projects/ghana-country-paper.pdf

Betts, A. (2011). Global migration governance. Oxford: Oxford University Press.

Black, R., \& King, R. (2004). Editorial introduction: Migration, return and development in West Africa. Population, Space and Place, 10(2), 75-83.

Bonjour, S., Ripoll Servent, A., \& Thielemann, E. (2018). Beyond venue shopping and Liberal constraint: A new research agenda for EU migration policies and politics. Journal of European Public Policy, 25(3), 409-421.

Börzel, T., \& Risse, T. (2003). Conceptualizing the domestic impact of Europe. In K. Featherstone, \& C. Radaelli (Eds.), The politics of Europeanization. Oxford: Oxford University Press.

Boswell, C. (2003). The 'external dimension' of EU immigration and asylum policy. International Affairs, 79(3), 619-639.

Carrera, S., Cassarino, J.P., El Qadim, N., Lahlou, M., \& den Hertog, L. (2016). EU-Morocco cooperation on readmission, Borders and protection: A model to follow? (CEPS Paper No. 87). Liberty and security in Europe. Retrieved from https://www.ceps. eu/system/files/EU-Morocco\%20Cooperation\%20Liberty\%20and\%20Security\%20in\%20Europe.pdf.

Cassarino, J.P. (2007). Informalising readmission agreements in the EU Neighbourhood. The International Spectator, 42(2), 179-196.

Cassarino, J.P. (2014). Channelled policy transfers: EU-Tunisia interactions on migration matters. European Journal of Migration and Law, 16(1), 97-123. 
Checkel, J. (2001). Why comply? Social learning and European identity change. International Organization, 55(3), 553-588.

Checkel, J. (2005). International institutions and socialization in Europe: Introduction and framework. International Organization, 59(4), 801-826.

Chou, M.-H., \& Gibert, M. (2012). The EU-Senegal mobility partnership: From launch to suspension and negotiation failure. Journal of Contemporary European Research, 8(4), 408-427.

Cross, H. (2013). Migrants, Borders and global capitalism: West African labour mobility and EU Borders. Routledge Research on the Global Politics of Migration. London: Routledge.

De Haas, H. (2008a). Irregular migration from West Africa to the Maghreb and the European Union: An overview of recent trends. IOM Migration Research Series, 32. Retrieved from http://publications.iom.int/system/files/pdf/mrs-32_en.pdf.

De Haas, H. (2008b). The myth of invasion: The inconvenient realities of African migration to Europe. Third World Quarterly, 29(7), 1305-1322.

Den Hertog, L. (2016). EU budgetary responses to the 'refugee crisis': Reconfiguring the funding landscape (CEPS Paper No. 93). Liberty and Security in Europe. Retrieved from SSRN: https://ssrn.com/abstract=2786930.

Devillard, A., Bacchi, A., \& Noack, M. (2015). A Survey on Migration Policies in West Africa. ICMPD/IOM. Retrieved from http:// publications.iom.int/system/files/pdf/survey_west_africa_en.pdf .

EEAS (2016). Joint Declaration on Ghana-EU Cooperation on Migration. Retrieved from https://eeas.europa.eu/headquarters/ headquarters-homepage/5249/joint-declaration-ghana-eu-cooperation-migration_en.

El Qadim, N. (2014). Postcolonial challenges to migration control: French-Moroccan cooperation practices on forced returns. Security Dialogue, 45(3), 242-261.

El Qadim, N. (2015). Le Gouvernement Asymétrique des migrations [The Asymmetric Governance of Migration]. Maroc/Union Européenne. Paris: Dalloz.

European Commission (2016). Communication from the Commission to the European Parliament, the European Council, the Council and the European Investment Bank: On establishing a new Partnership Framework with third countries under the European Agenda on Migration (COM/2016/0385 final). Retrieved from https://eur-lex.europa.eu/legal-content/EN/TXT/ ?uri=CELEX\%3A52016DC0385.

European Commission (2017). Annexe N à l'Accord Instituant le Fonds Fiduciaire [Annex IV to the Agreement Establishing the Trust Fund]'European Union Emergency Trust Fund for stability and addressing root causes of irregular migration and displaced persons in Africa', et ses règles internes [and its internal rules] (Project action fiche. Reference: T05EUTF-SAH-SN-06). Retrieved from https://ec.europa.eu/trustfundforafrica/sites/euetfa/files/t05-eutf-sah-sn-06_migration.pdf.

Eurostat (2018a). Third country nationals ordered to leave - annual data (rounded) (Dataset [migr_eiord]). Retrieved 15 June 2019 from http://appsso.eurostat.ec.europa.eu/nui/show.do?dataset=migr_eiord.

Eurostat (2018b). Third country nationals returned following an order to leave - annual data (rounded). (Dataset [migr_eirtn]). Retrieved 15 June 2019 from http://appsso.eurostat.ec.europa.eu/nui/show.do?dataset=migr_eirtn.

Finnemore, M., \& Sikkink, K. (1998). International norm dynamics and political change. International Organization, 52(4), 887.

Flahaux, M.-L., \& Kabbanji, L. (2013). L'encadrement des retours au Sénégal: Logiques Politiques et Logiques de migrants [The framework of returns in Senegal: Political logic and migrant logic]. In C. Beauchemin, L. Kabbanji, B. Schoumaker, \& P. Sakho (Eds.), Migrations Africaines: Le Codéveloppement en questions: Essai de Démographie Politique [African Migration: Codevelopment questions: A political demography essay] (pp. 241-279). Paris: Armand Colin.

Frowd, P. (2018). Security at the Borders: Transnational practices and Technologies in West Africa. Cambridge: Cambridge University Press. Ghosh, B. (2000). Return migration: Journey of Hope or despair? Geneva: IOM/UN.

Graziano, P., \& Vink, M. P. (2007). Europeanization: New research agendas. Basingstoke: Palgrave Macmillan.

Guiraudon, V. (2000). European integration and migration policy: Vertical policy-making as venue shopping. Journal of Common Market Studies, 38(2), 251-271.

Guiraudon, V. (2003). The constitution of a European immigration policy domain: A political sociology approach. Journal of European Public Policy, 10(2), 263-282.

Hampshire, J. (2016). Speaking with one voice? The European Union's global approach to migration and mobility and the limits of international migration cooperation. Journal of Ethnic and Migration Studies, 42(4), 571-586.

Katzenstein, P. (1984). Corporatism and change: Austria, Switzerland and the politics of industry. Ithaca: Ithaca.

Kingdon, J. W. (2014). Agendas, alternatives, and public policies, (4th ed.) New York: New York.

Koch, A., Weber, A., \& Werenfels, I. (2018). Profiteers of migration? Authoritarian states in Africa and European migration management (SWP research paper). German Institute for International and Security Affairs. Retrieved from https://www. swp-berlin.org/fileadmin/contents/products/research_papers/2018RP04_koh_et_al.pdf.

Lavenex, S. (1999). Safe third countries: Extending the EU asylum and immigration policies to central and Eastern Europe. Budapest: Central European University Press.

Lavenex, S., \& Schimmelfennig, F. (2009). EU rules beyond EU Borders: Theorizing external governance in European politics. Journal of European Public Policy, 16(6), 791-812.

Lavenex, S., \& Uçarer, E. (2004). The external dimension of Europeanization: The case of immigration policies. Cooperation and Conflict, 39(4), 417-443.

MAESE (2016). Fonds d'appui à l'investissement des Sénégalais de l'Exterieur - fiche de renseignement sur les critères d'éligibilité [Investment Support Fund for Senegalese Abroad - information sheet on eligibility criteria]. Retrieved from http://senegal. specicom.eu/pdf/Projet\%20FAISE.pdf.

Maillard, M., \& Costard, E. (2019, February 15). Présidentielle au Sénégal: Le vote « magique » de la diaspora de France. [Presential Elections in Senegal: the 'magic' vote' of the diaspora in France]. Le Monde. Retrieved from https://www.lemonde.fr/afrique/ article/2019/02/15/presidentielle-au-senegal-le-vote-magique-de-la-diaspora-de-france 5424095 3212.html.

March, J., \& Olsen, J. (1989). Rediscovering institutions: The organizational basis of politics. New York: Free Press.

Ministry of Finance of Senegal (2018). Politique nationale de migration du Sénégal [National Migration Policy of Senegal]. Dakar: Directorate-General for Human Capital.

Ministry of Interior of Ghana (2016). National Migration Policy for Ghana. Retrieved from http://migratingoutofpoverty.dfid.gov. uk/files/file.php?name=national-migration-policy-for-ghana.pdf\&site=354. 
Naudé, W., Siegel, M., \& Marchand, K. (2017). Migration, entrepreneurship and development: A critical review. IZA Journal of Migration, 6(5), pp. 1-16

Niang, A., \& Tandia, A. (2019). 2019 presidential elections in Senegal: Reflections on a west African model-democracy and the challenge of decolonization. Retrieved from https://kujenga-amani.ssrc.org/2019/04/03/2019-presidential-elections-insenegal-reflections-on-a-west-african-model-democracy-and-the-challenge-of-decolonization/ .

Paoletti, E. (2011). Power relations and international migration: The case of Italy and Libya. Political Studies, 59(2), 269-289.

Pollack, M. (2007). Rational choice and EU politics. In K. Jørgensen, M. Pollack, \& B. Rosamond (Eds.), SAGE handbook of European Union politics, (pp. 31-55). Thousand Oaks: SAGE.

Reslow, N. (2012). The role of third countries in EU migration policy: The mobility partnerships. European Journal of Migration and Law, 14(4), 393-415

Reslow, N., \& Vink, M. (2015). Three-level games in EU external migration policy: Negotiating mobility partnerships in West Africa. Journal of Common Market Studies, 53(4), 857-874.

Risse, T. (2000). 'Let's argue!': Communicative action in world politics. International Organization, 54(1), 1-39.

Robson, C., \& McCartan, K. (2016). Real world research: A resource for users of social research methods in applied settings (4th ed.) Chichester: Wiley.

Samers, M. (2004). An emerging geopolitics of 'illegal' immigration in the European Union. European Journal of Migration and Law, 6(1), 27-45.

Schimmelfennig, F., \& Sedelmeier, U. (2004). Governance by conditionality: EU rule transfer to the candidate countries of Central and Eastern Europe. Journal of European Public Policy, 11(4), 661-679.

Sinatti, G. (2018). Return migration, entrepreneurship and development: Contrasting the economic growth perspective of Senegal's diaspora policy through a migrant-Centred approach. African Studies. https://doi.org/10.1080/000201 84.2018 .1555310

Snidal, D. (2002). Rational choice and international relations. In W. Carlsnaes, B. Simmons, \& T. Risse (Eds.), Handbook of international relations, (pp. 73-94). London: SAGE Publications Ltd.

Teye, J. K., Alhassan, O., \& Setrana, M. (2017). Evolution and nature of diaspora engagement policies in Ghana. In J. R. Mangala (Ed.), Africa and its global diaspora: The policy and politics of emigration, (pp. 143-173). New York: Palgrave Macmillan.

Thielemann, E.R. (2001, May 31- June 2). The 'Soft' Europeanisation of migration policy: European integration and domestic policy change. Paper presented at the European Community Studies Association (ECSA) Seventh Biennial International Conference in Madison, Wisconsin. Retrieved from https://www.researchgate.net/publication/48909978_The_'soft'_ Europeanisation_of_migration_policy_European_integration_and_domestic_policy_change.

Trauner, F., \& Deimel, S. (2013). The impact of EU migration policies on African countries: The case of Mali. International Migration, 51(4), 20-32

Van Criekinge, T. (2010). The EU-Africa migration partnership: A case study of the EU's migration dialogue with Ghana and Senegal. Florence: EUI Migration Working Group.

Wunderlich, D. (2010). Differentiation and policy convergence against long odds: Lessons from implementing EU migration policy in Morocco. Mediterranean Politics, 15(2), 249-272.

Wunderlich, D. (2012). Europeanization through the Grapevine: Communication Gaps and the Role of International Organizations in Implementation Networks of EU External Migration Policy. Journal of European Integration, 34(5), 485503.

Zürn, M., \& Checkel, J. (2005). Getting socialized to build bridges: Constructivism and rationalism, Europe and the nation-state. International Organization, 59(4), 1045-1079.

\section{Publisher's Note}

Springer Nature remains neutral with regard to jurisdictional claims in published maps and institutional affiliations.

\section{Submit your manuscript to a SpringerOpen ${ }^{\circ}$ journal and benefit from:}

- Convenient online submission

- Rigorous peer review

- Open access: articles freely available online

- High visibility within the field

- Retaining the copyright to your article

Submit your next manuscript at $\boldsymbol{\nabla}$ springeropen.com 